\title{
Dengue virus infection in a French traveller to the hilly region of Nepal in 2015: a case report
}

\author{
Birendra Prasad Gupta ${ }^{1 *}$, Anurag Adhikari ${ }^{2}$, Ramanuj Rauniyar ${ }^{3}$, Roshan Kurmi ${ }^{4}$, Bishnu Prasad Upadhya ${ }^{5}$, \\ Bimlesh Kumar Jha ${ }^{5}$, Basudev Pandey ${ }^{6}$ and Krishna Das Manandhar ${ }^{1}$
}

\begin{abstract}
Background: Dengue viral infections are known to pose a significant risk during travel to tropical regions, but it is surprising to find dengue transmission in the hilly region of Nepal, which is over $1800 \mathrm{mtr}$ above sea level.

Case presentation: A 43-year-old Caucasian female traveler from France presented with fever and abdominal pain following a diarrheal illness while visiting the central hilly region of Nepal. Over the course of 9 days, she developed fever, body aches, and joint pain, with hemorrhagic manifestation. She was hospitalized in India and treated with supportive care, with daily monitoring of her platelets. An assessment by enzyme-linked immunosorbent assay showed that she was positive for dengue non-structural protein 1. Upon her return to France, dengue virus was confirmed by reverse transcriptase-polymerase chain reaction.

Conclusion: The district where this dengue case was reported is in the hilly region of Nepal, neighboring the capital city Kathmandu. To the best of our knowledge, there has previously been no dengue cases reported from the district. This study is important because it aims to establish a potential region of dengue virus circulation not only in the tropics, but also in the subtropics as well, which in Nepal may exceed elevations of $1800 \mathrm{mtr}$. This recent case report has raised alarm among concerned health personnel, researchers, and organizations that this infectious disease is now on the way to becoming established in a temperate climate.
\end{abstract}

Keywords: Dengue virus, Hilly region, Nepal, Travel

\section{Background}

Dengue is a mosquito-borne flaviviral infection that is endemic to the tropics and subtropics, affecting up to 100 million people per year [1]. The presentation of dengue virus (DENV) infection can be asymptomatic or manifest as a febrile illness; dengue fever. However, subsets of patients may develop dengue hemorrhagic fever, with complications such as gastrointestinal bleeding and ecchymoses, which may result in the potentially lethal form of the disease; dengue shock syndrome [24]. Around the world there are four distinct dengue virus serotypes (DENV 1-4) [5]. Interestingly, infection with one serotype confers serotype-specific immunity to

\footnotetext{
*Correspondence: birendraphd@gmail.com

${ }^{1}$ Virology Unit, Central Department of Biotechnology, Tribhuvan University,

Kritipur, Kathmandu, Nepal

Full list of author information is available at the end of the article
}

the host; however, if subsequent infection occurs with a different serotype, it can predispose the host to a grave clinical outcome [6-8].

Nepal shares an open border with India, an endemic region for DENV, thus is susceptible to an unprecedented flow of virus through infected patients crossing the border. Regulatory checkpoints and quarantines are not currently in place along the Nepali border. In 2013, a Nepali team isolated and characterized DENV circulating in a part of the eastern Terai that had previously seen cases of dengue in 2006 [9]. Comparing the data, Singh et al. [10] reported that, in fact, there were two different strains of DENV circulating in Nepal, raising the specter of an alarming dengue situation in Nepal.

We report a case of DENV infection in a Caucasian woman while she was traveling through the hilly region of Nepal. 


\section{Case presentation}

A 43-year-old Caucasian female arrived in Kathmandu from Paris, and the same day traveled to Kavre District, in the inner hilly region (elevation: 1800mtr) of Nepal. Nine days after arriving in the hilly region, she developed fever, body aches and joint pain. She also experienced loose stools and vomiting along with hemorrhagic manifestations such as facial flushing, petechiae and edema. She was subsequently admitted to a hospital in Goa, India, owing to health insurance requirements. Upon examination, her blood pressure and other vital signs were normal, without abdominal distension or bleeding. Ultrasonography of her abdomen and pelvis showed borderline splenomegaly $(12 \mathrm{~cm})$. An enzymelinked immunosorbent assay was positive for dengue non-structural protein 1, although tests for immunoglobulins $G$ and $M$ were negative. She was given supportive care, including intravenous fluids. Daily monitoring of her platelet count revealed values as low as $37,000 / \mathrm{mm}^{3}$ (Table 1). She was discharged from the hospital in Goa after 5 days, and returned to Paris, where she was hospitalized briefly and discharged. Dengue virus was confirmed by reverse transcriptase-polymerase chain reaction in Paris.

\section{Discussion}

The first case of DENV2 infection in Nepal was reported in 2004 in a Japanese traveler [11]. Subsequently, confirmed cases were reported from nine districts in the lowland Terai region of Nepal in 2006, and all four DENV serotypes were found to be co-circulating that year [9]. Over the years, the Terai belt, located south of the Himalayan foothills, has become an established dengue

Table 1 Laboratory parameters of dengue case

\begin{tabular}{ll}
\hline Test & Result \\
\hline Hemoglobin & $13.6 \mathrm{~g} / \mathrm{dL}$ \\
Packed cell volume & $39.1 \mathrm{~L} / \mathrm{L}$ \\
Platelets & $37,000 / \mathrm{mm}^{3}$ \\
Total bilirubin & $0.9 \mathrm{mg} / \mathrm{dL}$ \\
Direct bilirubin & $0.4 \mathrm{mg} / \mathrm{dL}$ \\
Serum glutamic oxaloacetic transaminase & $93 \mathrm{IU} / \mathrm{L}$ \\
Serum glutamic-pyruvic transaminase & $54 \mathrm{IU} / \mathrm{L}$ \\
Alkaline phosphatase & $53 \mathrm{IU} / \mathrm{L}$ \\
Total proteins & $7.7 \mathrm{~g} / \mathrm{dL}$ \\
Albumin & $4 \mathrm{~g} / \mathrm{dL}$ \\
Globulin & $3.7 \mathrm{~g} / \mathrm{dL}$ \\
Albumin to globulin Ratio & 1.08 \\
Gamma-glutamyl transferase & $45 \mathrm{IU} / \mathrm{L}$ \\
Dengue immunoglobulin G and M & Negative \\
Dengue non-structural protein 1 antigen & Positive \\
\hline
\end{tabular}

region. However, only limited data have been generated about DENV infection and disease in Nepal. Two major outbreaks have occurred in Nepal: one in 2010, dominated by DENV1, and the other in 2013, dominated by DENV2 $[10,12]$. Dengue was reported in the highlands for the first time during the 2010 outbreak [12]. The 2013 outbreak also affected the highlands, including Kathmandu, though it was predominantly confined to Chitwan, Rupandehi, Parsa, and Dhanusa [10]. The shift of the viral disease from the subtropical Terai belt to the temperate hill region of Nepal is relevant to medical science because the disease could easily spread all over the world in the future, irrespective of climate [13]. The village to which the patient had traveled is at an elevation of $1800 \mathrm{mtr}$. It is becoming apparent that DENV is adapting to temperate climates as well. This may be because of temperature change due to global warming, the resistance of mosquitoes to drugs, or other factors, all of which may have contributed to the increase in dengue fever cases around the world in recent years.

Reports of dengue among travelers worldwide have been increasing, but high-quality data on incidence are lacking. The increase in international travel to dengue-endemic regions, with the associated risk of travel-acquired dengue, poses a serious concern [14]. The shift in temperature around the world has enabled DENV to thrive in colder regions where it was previously not reported. To look for the causes, the mosquito vector Aedes spp. and mutations in the virus should be the foci of future research. $A$. aegypti was first reported in Kathmandu in 2010 and the vectors may have now established populations up in the mountains [12]. Serotype and genotype shifts have been reported based on sequencing of specific viral regions [15]. In-depth molecular study of the virus found in the hill region of Nepal might give insights into the climatic shift of dengue disease. Therefore, the authors strongly recommend active surveillance and identification of mosquitoes along with whole genome sequencing of the virus for greater awareness as well as knowledge of dengue fever and dengue hemorrhagic fever transmission.

\section{Conclusion}

This is the second report of DENV infection in a foreigner travelling in Nepal, after the case in a Japanese traveler reported in 2004. Although initially it was thought that only the Terai belt of Nepal was endemic for dengue, a number of dengue cases are also being reported from the hill region. The Government of Nepal should take the initiative to eliminate adult mosquitoes, as well as larvae and eggs, to prevent further transmission of arboviruses in the hill region of Nepal, which is one of the most attractive touristic sites in Nepal. 


\section{Consent}

Written informed consent was obtained from the patient for publication of this case report and any accompanying images. A copy of the written consent is available for review by the Editor-in-Chief of this journal.

\section{Competing interests}

The authors declare that they have no competing interests.

\section{Authors' contributions}

BPG, AA, and RR designed the study. BPG, AA, RK, BPU, and KDM collected data from the patient. BPG, AA, BPU, BDP, BKJ, and KDM wrote the paper. All authors read and approved the final manuscript.

\section{Acknowledgement}

The authors are very grateful to Lisa Krain from Johns Hopkins Bloomberg School of Public Health, Maryland, USA, for her thorough language editing of the manuscript. The authors also would like to thank the doctors, nurses, and laboratory staff for supportive treatment, care, and diagnosis in the case.

\section{Author details}

${ }^{1}$ Virology Unit, Central Department of Biotechnology, Tribhuvan University, Kritipur, Kathmandu, Nepal. ${ }^{2}$ Asian Institute of Technology and Management, Purbanchal University, Lalitpur, Nepal. ${ }^{3}$ Everest School of Applied Science, Kathmandu, Nepal. ${ }^{4}$ Bhawani Hospital and Research Center, Birgunj, Nepal. ${ }^{5}$ National Public Health Laboratory, Teku, Kathmandu, Nepal. ${ }^{6}$ Leprosy Division, Ministry of Health, Government of Nepal, Kathmandu, Nepal.

Received: 27 January 2016 Accepted: 23 February 2016

Published online: 21 March 2016

\section{References}

1. Kosasih H, Alisjahbana B, Nurhayati, de Mast Q, Rudiman IF, Widjaja S, et al. The epidemiology, virology and clinical findings of dengue virus infections in a cohort of Indonesian adults in Western Java. PLoS Negl Trop Dis. 2016; 10(2):e0004390.

2. Zhang $\mathrm{H}$, Zhou YP, Peng HJ, Zhang XH, Zhou FY, Liu ZH, et al. Predictive symptoms and signs of severe dengue disease for patients with dengue fever: a meta-analysis. Biomed Res Int. 2014;2014:359308.

3. John DV, Lin YS, Perng GC. Biomarkers of severe dengue disease - a review. J Biomed Sci. 2015;22:83.

4. Sharma K, Yadav A. Association of mean platelet volume with severity, serology \& treatment outcome in dengue fever: prognostic utility. J Clin Diagn Res. 2015;9(11):EC01-03.

5. Henchal EA, Putnak JR. The dengue viruses. Clin Microbiol Rev. 1990;3(4):376-96.

6. Guzman MG. Global voices of science. Deciphering dengue: the Cuban experience. Science. 2005;309(5740):1495-7.

7. Halstead SB. Neutralization and antibody-dependent enhancement of dengue viruses. Adv Virus Res. 2003;60:421-67.

8. Endy TP, Nisalak A, Chunsuttitwat S, Vaughn DW, Green S, Ennis FA, et al. Relationship of preexisting dengue virus (DV) neutralizing antibody levels to viremia and severity of disease in a prospective cohort study of DV infection in Thailand. J Infect Dis. 2004;189(6):990-1000.

9. Malla S, Thakur GD, Shrestha SK, Banjeree MK, Thapa LB, Gongal G, et al. Identification of all dengue serotypes in Nepal. Emerg Infect Dis. 2008; 14(10):1669-70.

10. Singh S, Gupta BP, Manakkadan A, Das Manandhar K, Sreekumar E. Phylogenetic study reveals co-circulation of Asian II and Cosmopolitan genotypes of dengue virus serotype 2 in Nepal during 2013. Infect Genet Evol. 2015;34:402-9.

11. Takasaki T, Kotaki A, Nishimura K, Sato Y, Tokuda A, Lim CK, et al. Dengue virus type 2 isolated from an imported dengue patient in Japan: first isolation of dengue virus from Nepal. J Travel Med. 2008;15(1):46-9.

12. Pandey BD, Nabeshima T, Pandey K, Rajendra SP, Shah Y, Adhikari BR, et al. First isolation of dengue virus from the 2010 epidemic in Nepal. Trop Med Health. 2013:41(3):103-11.

13. Dhimal M, Gautam I, Kress A, Muller R, Kuch U. Spatio-temporal distribution of dengue and lymphatic filariasis vectors along an altitudinal transect in Central Nepal. PLoS Negl Trop Dis. 2014;8(7), e3035.
14. Dhimal M, Gautam I, Joshi HD, O'Hara RB, Ahrens B, Kuch U. Risk factors for the presence of chikungunya and dengue vectors (Aedes aegypti and Aedes albopictus), their altitudinal distribution and climatic determinants of their abundance in central Nepal. PLoS Negl Trop Dis. 2015;9(3), e0003545.

15. Gupta BP, Singh S, Kurmi R, Malla R, Sreekumar E, Manandhar KD. Re-emergence of dengue virus serotype 2 strains in the 2013 outbreak in Nepal. Indian J Med Res. 2015;142 Suppl: S1-6.
Submit your next manuscript to BioMed Central and we will help you at every step:

- We accept pre-submission inquiries

- Our selector tool helps you to find the most relevant journal

- We provide round the clock customer support

- Convenient online submission

- Thorough peer review

- Inclusion in PubMed and all major indexing services

- Maximum visibility for your research

Submit your manuscript at www.biomedcentral.com/submit 